\title{
African Big Economies on the Continental Trade Liberalisation and Migration Policy Development
}

\author{
Andrew Osehi Enaifoghe, Harris Maduku \\ University of Zululand, X1001, KwaDlangezwa, KwaZulu-Natal South Africa \\ *andyransey@gmail.com, madhukuharris@gmail.com
}

\begin{abstract}
African countries are faced with a broad spectrum of political and economic challenges that have shadowed hugely in an anticipated socio-economic prosperity. The continent overtime has resolved to come up with a single currency as well as opening borders for trade but none of that has been realised. Polarisation of economic development has caused brain drain within the continent with educated people from poorly governed countries moving across borders (Europe and America), and the same happens with gifted entrepreneurs who search for a country with a better business enabling environment than their own home countries. There is uneven development in Africa with very poor, fragile and better performing countries constituting the continent. This has caused a huge burden on those economies that are doing well as those economies have to create jobs for immigrants as well and for their own people. However, the founding principles of the African Union were basically to bring African countries together and help each other to see through economic and political prosperity across the continent in as much as there are laid out guiding rules. Africa has continued to be a highly protective continent especially amongst itself as most countries still require visas from citizens of other African countries, while countries still impose import duties and all forms of control on imports and practices that are against the foresights of the founding principles of the African Union. This paper acknowledges the efforts that have been done in the West and South of Africa for the formation of regional blocks that desire to achieve socio-economic progress in those regions. The formation of ECOWAS in the WEST and SADC in the South are good strides towards integration efforts in Africa but if the founding objectives of the African Union are to be achieved, member countries still have to do more. This paper recommends the two biggest countries in Africa to make use of their economic power to influence smaller member states to also envision possible socio-economic benefits that can emanate from total integration of the continent. They could make use of the African parliament, African Union summits and other several platforms to lobby for this important goal.
\end{abstract}

Keyword: Economic development, trade, integration, liberalisation, immigrants.

\section{Introduction}

Apparently countries around the world including those in Africa have over the years continue to engage with each other through the means of trade, because trading typically makes a country better off which creates income and enhance social and economic development through exchange. In global exchange, competition happens at the firm level, while citizens of each nation may profit by a facilitated or free trade. Nationals appreciate a more significant variety of goods and ventures, and by and large at a lower cost (Martin, 2005). The withdrawal or decrease of restrictions that hinder free trade between countries is eluded to be the advancement of exchange (liberalisation of trade). This incorporates the expulsion of exercise duty deterrents, for example, duties charges, and non-tariff hindrances that is permitting principles, shares and different needs, which facilitate integration. Trade Integration development is the decline of exchange practises, that shambles free movement of merchandise and enterprises opening with one country to another. The facilitating of these limitations is regularly alluded to as evolving "systematized trade".

Those against exchange advancement argued that it can cost jobs as less expensive goods surge the market (World Bank, 2013). However, exchange development eventually brings down consumer costs, expands productivity and cultivates monetary development. This paper argues that a complete tariff abolishment together with significantly reducing nontariff barriers can actually improve economic growth and raise the volume of exports and imports while significantly improving the terms of trade across Africa. In order for the integration agenda to be achieved, member countries need to abolish non-tariff barriers, speed up the development and modernization of infrastructure, specifically trade-enabling infrastructure, and raise the level of resources allocated to the financing of intra-African trade. As of 2016, the African Union (AU) recorded its three major importers in the name of Egypt, South Africa and Algeria whilst on the other side its 
biggest three exporters were South Africa, Nigeria and Angola. This category of big importers and importers accounted for a total of $39 \%$ of $\mathrm{AU}$ imports and exports.

According to African Trade Report (2018), the share of Intra African trade in Africa's total imports and exports continue to hit their low. Statistics released by the bank show a recorded $13 \%$ for intra-imports and $17 \%$ for intra exports over the period of the last seven years. While the value of total exports diminished, the share of intra-exports trade increased by $30 \%$ in 2016 in comparison with 2010. Outside Africa trade makes up more than $80 \%$ of the total African trade. The volume of exports to other continents and imports from other continents is similar and on average Africa receives 450 billion USD from exports and spends 490 billion USD on imports from other continents. The leading countries on the trade arena are South Africa and Nigeria. South Africa is the main player in Intra African trade with a share in intra exports which varies from 27 to $30 \%$ over the period of 7 years followed by Nigeria with 8\% (African Trade Report 2018). However, much hasn't been done to cover the aspect of migration to promote peaceful co-existence, which is the motivation behind this study. Despite the fact that integration has been set up by some African nations.

The arrangement of the European Union (EU) serves as a motivation and reinforced numerous other African nations' quest for an amassed African landmass be that as it may, given the present crisis confronting the euro zone and its effect on the exclusive political structures (Candice, 2004). A more profound provincial incorporation is part of the answer for accomplishing economies of scale and improved development, particularly for littler less created nations in Africa. The continent of Africa is apparently home to 1 billion people scattered crosswise over 54 nations whose joined GDP was US $\$ 1,871$ billion in 2011 (World Bank, 2013). Regional economic integration has become an exceptionally applicable issue in Africa, especially in light of its existing political and financial shortcomings. Africa is invaded with the most profound levels of poverty, and without a doubt Africa could be viewed as the most reduced share of world trade, and furthermore the weakest progress in human capital development, as well as structure but endowed with abundance of materials and talents. It is as a direct result of this that territorial integration is required in Africa, as this tended to upgrade continent's monetary advancement and economic development. This study therefore concentrates principally on trade liberalisation import for economic development in Africa.

With the economic investment and trade liberalisation within the sub-regions to promote peace and sustainability this could be done through the existing various sub-regional institutions. This study therefore influenced by the thoughts of other scholars who are of the opinion that regional economic incorporation will further aggravate African economic problems. These incorporate the East African Community (EAC), the Southern African Development Community (SADC), the Common Market for Eastern and Southern Africa (COMESA), the Economic Community of West African States (ECOWAS), the Economic Community of Central African States (ECCAS), the Community of Sahel-Saharan States (CEN-SAD) and the Arab Maghreb Union (AMU). It is critical to note here that the European Union (EU) remain one of the most proficient regional integration institution in the world today, which has practically comparative targets as those relevant to the Africa's regional integration (Enaifoghe, 2019). Africa's exceptional physical, economic and political geography position made it difficult to achieve economic development, and the administration of shared public goods. Political fringes are regularly not adjusted to economic and natural resources and numerous nations are landlocked.

\section{Method and Materials}

The researchers adopted a qualitative research approach as the suitable research technique or method for this study. Data was collected from numerous secondary bases predominantly from journal article, reports from government and non-government organizations, book and others source. Secondary research is based on secondary resources that already available (Mouton, 2001). The researchers therefore used content analysis which allows researchers to study, and make sense of transcribed materials or documents (Mogalakwe, 2006). The researchers therefore determined the relevance of the documents that they consult on the basis of their significance to the subject understudy. Furthermore, Dey (2005, p.105) argues that "in documented or content analysis, the criteria for selecting documents, or for focusing on particular extracts, should reflect the issues on which the researcher is seeking evidence." This method made it possible for the researchers to explore various existing literature on African economic integration with regards to trade 
liberation, both the economic and political factors that may have hindered the complete implementation of the agenda. Over 30 literatures were assessed but only 23 literatures were found very relevant to inform the study, the various literatures were accessed from Google scholars, Scopus and sources.

\section{Literature Review}

In order to establish the significance of this study, and to display the existing studies relevant to this current study area, the preliminary literature review in this study focuses on both the socio-economic and political factors responsible for the African regional integration organizations for level of economic development experienced in various sub-regions. Regional integration has been seen to be a key force for a sustainable development around the world today. Hence it can promote economic growth, reduce poverty, foster social development or protect the environmental issues. Nevertheless, it can as well have a negative impact on both economic and social aspects, notably if the regulatory framework on domestics becomes inadequate or not effectively implemented. The Southern African Development Community (SADC), continue expansion of the current integration processes in the sub-region amongst its members as its main commitment, has therefore adopted the Regional Indicative Strategic Development Plan (RISDP), this is to provide strategic direction in the design and formulation of SADC programs, projects and activities so as to achieve it development objectives and economic growth, alleviate poverty, enhance the standard and quality of life of the people of Southern Africa and support the socially disadvantaged, through regional integration (Enaifoghe and Adetiba, 2018).

Nonetheless, many African nations progressively perceive that communitarian or collaborative activities and regional approaches are basic to accomplishing their advancement or development objectives. According World bank, one of the advantages from seeking after regional incorporation or integration are bunch, including: the procuring economies of scale or different efficiencies by acting collectively in the quest for common goals to expand local supply capacity or limit, and further enhance access to business sectors; a coordinated or orchestrated treatment of trans-limit issues, for example, exchange, administrative systems and strategies, territorial framework and different cross fringe issues; and the administration of shared characteristic assets (The World Bank, 2013). These arrangements are especially significant for the numerous African nations that have small economies, small populations or are land-bolted. Little nations regularly think that it's hard to subsidize the huge settled expenses related with significant foundation, making a regional approach alluring. Connecting little markets can open the advantages of agglomeration and scale economies and spread speculation openings and development past current focuses of improvement (Enaifoghe, 2019) it was further stated by Enaifoghe that most Regional Economic Communities (RECs), particularly.

The African sub-regional institutions, and other territorial development organisations, are creating vital regional structures and capacity that could enable it seeks after integration regionally and over different regions. There is a developing interest to scale up regional arrangements with a more prominent concentrate on mainstreaming regional issues in national planning, handling the environmental change drive, regional infrastructure and the missing connections, the economic integration, investment on human capacity building, peace and security and regional public goods (Enaifoghe, 2019). Furthermore, in line with the World Bank's territorial program, it is critical to the effort of moving Africa's regional incorporation motivation forward, in a close coordinated effort with the member states and other advancement parties. The diversity of Africa's array of provincial organisations are as of now advancing more prominent political and monetary reconciliation among neighbouring nations, thereby handling shared asset administration issues. Currently, at the continental level, the African Union tries to join African nations under a solitary political union and basic market. At the provincial level, Africa's Regional Economic Communities unite nations to address regular advancement challenges and extend both economic and political cooperation integrated.

Africa's regional specialized bodies concentrate on particular cross-fringe issues, for example, river basin administration, local power exchanging and cross-outskirt infection transmission. Reinforcing the limit of these establishments is basic to quickening the incorporation incentive (The World Bank, 2013). Regional Integration Institutions (RIIs) otherwise called Regional Economic Communities (RECs), was resulting from the introduction of the Abuja (Nigeria) Treaty of the then Organization of African Unity (OAU) which came into force in May 1994 (UN Economic Commission for Africa, 1999:53). That Treaty visualizes the production 
of an African Economic Community through six periods of regional participation and reconciliation with the utilization of the regional integration institutions (RIIs) as its guiding structure. Principally the main point and goal of these organizations is to realize social, economic and even political incorporation among Africa's nations in order to achieve higher economic development and reinforcing the flourishing of the people of Africa. In regards to the above, the previous two decades particularly, have seen an escalation of Africa's provincial.

Joining process of integration and the establishment or the fortifying of RIIs in Africa, Robson (1968) noted that economic integration between sovereign states becomes a trend in the mid-twentieth century and the increasing formation of such integrated bodies has led to this era being termed 'the age of integration'98. This need for integration is manifested in the establishment of organizations such as the European Economic Community (EEC), the European Free Trade Area (EFTA), the Central American Common Market, and the Arab Common Market across the developed, Latin American and Middle Eastern world respectively (Mauro, 2000). With the formation of institutions such as the Southern African Custom Unions (SACU), African countries have increasingly joined the integration bandwagon and their interest not only comes from the economic benefits of such bodies but is also as a result of the political and social aspects, all of which are closely associated to one another high priority in the political agenda of many African countries and its importance is associated with the need to form strong Regional Economic Integration (REI) mechanisms which would in turn lead to an increase in economic growth through the convergence of macroeconomic and fiscal policies, and an increase in intra-regional trade. The integration of states is a complex process which cannot be explained by a single theory.

Several theories in international relations argue for the interdependency and cooperation of states as a means of not only helping to overcome the disadvantages of small size. Then surviving the current economic and political environment (Langenhove, 2004), is also as a result of impact of globalization on the world economy, where the local has interpenetrated the global and vice versa. This has led to the issue of boundaries and/or frontiers among states becoming socio-economically imaginary and as such, these challenges would need to be turned into opportunities. Furthermore, regionalization and globalization have increasingly become tag-lines which are used to characterize the development and evolution of the world's economy in the post-war era and states would need to be more organized in order to meet up with these exigencies brought about by the globalized economy. While globalization is used to refer to the global liberalization of trade and factor flows, regionalization on the other hand is used to characterize the increasing number of regional integration blocs (Langenhove, 2004). Njinkeu and Mangeni, (2004), argued that the issue of economic integration between African countries has continued to deepen over the past decades and Africa currently contains a wide range of Regional Economic Communities (RECs) which can be divided into two main categories.

Those recognized by the AU and sub-regional economic communities (also known as SECs) (Njinkeu and Mangeni, 2004). The AU only recognizes eight RECs which they consider to be the building blocks of a greater African integration21; however, other SECs have been known to play a significant influence in sub-regional politics (Njinkeu and Mangeni, 2004). In spite of the scholarly works on Africa regional integration on trade liberation some scholars still holds the view that integrating African economies through a regional economic incorporation will aggravate African economies than they are currently. This work identifies the paucity of literature in this area of study, and seeks to covers such gaps, by contributing significantly to the body of knowledge. The primary focus is on the socio-economic aspects regards to trade development, mobilization and implementation of its blueprint and policy, Nigeria and South Africa as the main drivers of the ECOWAS and SADC trade liberalization in the sub-regions, using various mechanisms and strategies, the question is who benefit from the trade liberalization? The member states of a sub-regional organisation are not at the same level of preparedness to commit to the organisational policy implementation of its objectives for example; Malawi, Mozambique, Tanzania and Zimbabwe are not up to date.

The principal aim of this study is to explore the socio-economic factors at play in the implementation and liberalization of trade in both ECOWAS and the SADC sub-regional integration related to this therefore are others sub aims including; to investigate the thoughts of other scholars. Whose view on regional economic incorporation on trade liberalization will further aggravate African economies than they are currently with 
regards to trade and movement of persons across border? To determine a more effective ways for smaller nations to achieve economic development, since the strength of vast economies makes chances to lift other smaller economies through regional exchange with trade. To investigate the liberalization of trade within two sub-regions of Africa (SADC and ECOWAS), and who are the benefactors - member states or the divers. To determine to what extent is trade liberalized with the member states or rather with the outsider to create competition within the sub-regions, To investigate why the liberalization of trade tend to benefits the drivers of sub-regional institution's objectives for national development and what South Africa can learn from Nigeria and ECOWAS. With respect to exchange, the SADC was to accomplish a Free Trade Area by end of 2008 and furthermore start a SADC Customs Union by 2010 (Department of Economic Affairs, African Union, 2008).

The Renewed Interest in the Africa Economic Integration Development: The southern Africa or Southern Africa is a term used to generally include the following countries Angola, Botswana, Lesotho Malawi, Mozambique, Namibia, South Africa, Swaziland, Zambia, and Zimbabwe. However, the region is said to be unipolar with South Africa as a first regional power in a political perspective (Schenoni, 2017). Broadly viewed, African regional cooperation has been revitalised in some ways due to two main developments at the beginning of the 1990s that include the abolition of the apartheid regime in South Africa, and the eventual stabilisation of political and economic relationships in the Southern Africa sub-region. This helped deepen the already existing regional integration in the Southern Africa States, Enaifoghe and Adetiba, (2018: 4). Cheru (2002) noted that since the end of the Cold War, and with the emergence of powerful trading blocs, there has been a renewed interest in South Africa regarding the need to create strong REI mechanisms to promote economic growth for the region.

South Africa in the Southern Africa Integration Efforts: In 1980, nine Southern African states - Angola, Botswana, Malawi, Mozambique, Lesotho, Swaziland, Tanzania, Zambia and Zimbabwe - set up the Southern African Development Co-appointment Conference (SADCC). The principle target of this organisation was to decrease its individuals' monetary reliance on the Republic of South Africa, additionally to begin the procedure of provincial political and financial integration between these alleged forefront states. Within the two last decades ago the association has changed from an advancement or development conference into a development community -currently known as the SADC. It has likewise extended its topographical scope to cover six more states - the Democratic Republic of Congo, Mauritius, Namibia, the Republic of South Africa, Madagascar and the Seychelles - and it points today at a profound combination, yet so far has accomplished almost just a few. By the year 2005, SADC was yet to set up the primary phase of financial incorporation, which is the free trade area (FTA) among its member states by the year 2008 but finally accomplished it in 2010 (SADC (2003a).

According to Enaifoghe and Adetiba (2018: 7) "the SADC has experienced a thorough rearrangement or change with South Africa turning into its true front-runner as opposed to her essential aim. Amongst the fundamental goals of SADC are to accomplish advancement and monetary development, lighten neediness, improve the standard and personal satisfaction of the general population of Southern Africa and support the socially disadvantaged through territorial incorporation or integration. It pursues other objectives such as propelling basic political quality frameworks and foundations, progression and ensuring peace and security. "Nevertheless, "The SADC has appears to be among the best integrated sub-region in Africa aided largely by South Africa's material, commodity and political investment" (Enaifoghe and Adetiba, 2018). As far as integrating the organisation is concerned, the SADC has recorded accomplishments on structure and restoration of transportation connection among its member states. However, the free trade area was only accomplished on August 2008 as expected, regrettably missing the 2010 deadline for the establishment of custom union.

While the SADC (South African Development Community) met in 2015 to negotiate a new target date for the transformation of the organisation into a Customs Union (CU), during the 2015 Ordinary Summit, nevertheless SADC has not yet achieved the establishment of custom union in the sub-region by end of 2016 (Enaifoghe, 2019). In as much as it seem like the SADC region is organised, this block has no much power to influence policy among member states. The bigger part of the region's member states are struggling economically and there is limited or no intervention that has happened either from member states or the block itself. Countries like Zimbabwe, Malawi and Madagascar are not doing well economically with 
Zimbabwe in worst situations compared to those three and the lack of intervention from the block has negatively affected the region because the economic contribution from Zimbabwe has been deteriorating on a yearly basis so as that of the other mentioned member states of the SADC region. However, in terms of political stability, the SADC region has maintained peace for a very long time and it is one of the achievements that can be forged to be credited on the SADC region. On the socio-economic front, little has been achieved by the block since the majority of the member states have high poverty rates that are above $50 \%$ with South Africa included (UN ECA, 2017).

Nigeria in the Western Africa Integration Efforts-ECOWAS: The Economic Community of West African States, otherwise called ECOWAS, and in French: "Communauté économique des États de l'Afrique de l'Ouest, CEDEAO; Portuguese: Comunidade Económica dos Estados da África Ocidental, CEDEAO, is a regionals financial union of fifteen nations located in the Western part of Africa." In 2015 had an expected populace of more than 349 million the union was built up on 28 May 1975, with the marking of the Treaty of Lagos, with its expressed mission to advance financial or economic combination over the area (Adeyemi, 2003 and Yahoo News AFP, 2017). A reconsidered form of the bargain was concurred and marked on 24 July 1993 in Cotonou. Considered one of the pillar provincial coalitions of the landmass wide African Economic Community (AEC), the state's objective of ECOWAS is to accomplish "aggregate independence" for its part states by making a solitary vast exchanging alliance by building a full financial and exchanging union. ECOWAS additionally fills in as a peacekeeping power in the district, with members at times sending joint military powers to mediate in the coalition's part nations on occasion of political unsteadiness and turmoil. This paper believes that if fully integration can be done and the free trade corridors can be opened for the region, that can facilitate resources to flow where they are less utilised to where they are needed the moist and that can help the economy of the continent to grow significantly to alleviate citizens of the continent from socio-economic problems of poverty, unemployment and inequality.

In the African continent, the Southern Africa occupies the southernmost region of the continent, variably defined by geography or geopolitics. As of late these included mediations in Ivory Coast in 2003, Liberia in 2003, Guinea-Bissau in 2012, Mali in 2013, and Gambia in 2017 (Adeyemi, 2003 and Yahoo News AFP, 2017). ECOWAS incorporates two sub-territorial alliances: The West African Economic and Monetary Union (known by its French-dialect acronym UEMOA) is an association of eight, basically French-speaking states in the ECOWAS sub-region which share a customs union and currency union. It was set up in 1994 and expected to balance the predominance of English-speaking economies in the alliance, (for example, Nigeria and Ghana), individuals from UEMOA are for the most part previous domains of French West Africa. The currency they all accept is the CFA franc, which is pegged to the euro. The West African Monetary Zone (WAMZ), set up in 2000, involves six for the most part English-talking nations inside ECOWAS which plan to work towards receiving their own basic money, the eco. ECOWAS works in three co-official dialects-French, English, and Portuguese, and comprises of two foundations to execute engagements: the ECOWAS Commission and the ECOWAS Bank for Investment and Development (EBID), in the past known as the Fund for Cooperation until it was renamed in 2001.

There is high brain drain from countries such as Mozambique, Zimbabwe, Zambia and Malawi into South Africa, mostly because the socio-economic front has not achieved any significant strides in the region. In 1976 Cape Verde joined the ECOWAS regional block, and in December 2000 Mauritania pulled back, having declared its expectation to do as such in December 1999. In 2011, ECOWAS embraced its improvement outline for the following decade, Vision 2020, and, to go with it, a Policy on Science and Technology (ECOPOST). Nevertheless, "it is argued that the SADC is seen to be lagging behind the Economic Community of West Africa States (ECOWAS) and the Common Market for East and Southern Africa (COMESA) particularly in both social and economic development of their members" (Enaifoghe, 2018). In any case, The World Bank has for quite some time been a champion of regional incorporation issues and has altogether scaled up support as of late after the dispatch of the Africa Regional Integration unit in 2004. World Bank relentless support for regional activities remains multi-frame: Financing and counselling administrations for territorial speculation programs, specialized help and investigative work on incorporation issues, and limit working for local institutions- utilizing the Bank's gathering energy to attract consideration regarding the mix motivation and use joint effort and assets from giver accomplices and the private segment. 
The Biggest Economies in the Trade Liberalization: South Africa and Nigeria are the biggest economies in Africa with Nigeria being the biggest in GDP terms and South Africa being the most industrialised economy on the continent. Surely these two countries play a huge role in terms of intra African trade and they are expected at least in the context of this paper to play extra roles than other countries. Nigeria is reported to be the biggest recipient of Foreign Direct Investment (FDI) in the ECOWAS region but its exports into that region have remained very low as well as its imports from the region. This is despite various opportunities that are offered by ECOWAS member states in the region. On the outset, South Africa enjoys almost the same benefits in relation to the FDI receipts in the SADC region but its imports from the region are quite very low despite its corporates enjoying a huge market from struggling economies such as Zambia, Malawi and Zimbabwe. South Africa and Nigeria still view the African Union member states as their potential market rather than taking them as partners as far as economic development is concerned. The time these two big economies start to understand that other African member states are not simply their clients this will short change the polarised industrial development that is witnessed in Africa at the current moment. A wide spread industrial development as a result of partnership among African states shall help to improve the value addition and stop Africa from trading primary products.

The biggest sector making Africa lose millions of jobs that it could be offering to its citizens is the mining sector. South Africa is a country with a huge mining sector but it has not developed to an extent of exporting processed or manufactured mining products and this is making the region billions in potential income. The same happened to Nigeria in the context of oil products. Nigeria can work as a refinery for oil producing African states and Africa can be the biggest exported of refined oil products but this can be realised on if it starts viewing other oil producing African country as neighbours but as partners in economic development through reducing the amount of jobs that the region is exporting to Europe through exportation of primary products. Nigeria and South Africa can facilitate and influence the region to achieve full economic integration also through their huge network of huge companies that are operational in the region already. These big companies can be useful to the economic integration agenda either as funders or through policy recommendations.

These companies have seen the potential partnerships they can exploit as well as their growth prospects that are hindered by lack of integration in the region. On the other side, these two big economies are better resourced compared to other member states and lack of funding has been cited in the literature (UNECA 2006) as one of the problems dampening efforts of economic integration. In that regard they can come in as resource mobilisers for the attainment of economic integration which is evident that they might one of the biggest beneficiaries. To add, since they are the biggest economies, South Africa and Nigeria can partner with other member states to influence infrastructure development to ensure that there is easy and cheap transportation of goods from one country to another advancing the interests of integration? As much as it is evident that the two countries have been huge supporters of African Economic Integration, it does not show that its implementation urgency is not one of their politics priorities and that can have contagious effects to other small countries in the region who are members states to the African Union.

\section{Conclusion and Recommendations}

Despite the known and bold spelt economic development efforts that are known to be realised by all African states as result of a fully integrated Africa, little has been done to achieve that goal. The founding objectives of the Organisation of African Unity (OAU) which later became the African Union (AU) are very clear as far as free trade and single currency are concerned for Africa. Since 1963, Africa still has trade barriers amongst member states as well as travelling visas. However, efforts have been done as far as bilateral arrangements are concerned. Also the western part of Africa has made huge strides in bringing the member states of that sub-region together in trade terms and security. On the other front, Southern Africa as well through the formation of the SADC showed that it is possible to bring member states together for a common agenda. However, these organisations that have emerged in these two corners of Africa have not done enough as far as spreading this to the whole of Africa and there are better results and benefits for all Africans if the African Union can manage to make all the members states and if not all, the majority of its member states speak with one voice. The AU has been challenged that it has never has much power but a mere secretariat organisation for the continent but its member states have more power. Just as in this study we focused on both the power 
play on the socio-economic and political factors, which are responsible for the African regional integration organizations through the liberalization of trade for a leveled economic development experienced in various sub-regions.

Regional integration has been seen to be a key force for a sustainable development around the world today. Hence it can promote economic growth, reduce poverty, foster social development or protect the environmental issues. Nevertheless, studies find that, it can as well have a negative impact on both economic and social aspects, notably if the regulatory framework on domestics becomes inadequate or not effectively implemented. The Southern African Development Community (SADC) through South Africa, continue expansion of the current integration processes in the sub-region amongst its members as its main commitment with trade penetration. It has therefore adopted the Regional Indicative Strategic Development Plan (RISDP), this was meant to provide strategic direction in the design and formulation of SADC programs, projects and activities so as to achieve it development objectives and economic growth, alleviate poverty, enhance the standard and quality of life of the people of Southern Africa and support the socially disadvantaged, through regional integration. Nonetheless, many African nation, has progressively perceived that communitarian or collaborative activities and regional approaches are basic to accomplishing their advancement or developmental objectives. The World banks also viewed that one of the advantages from seeking after regional incorporation or integration cluster, including the procuring economies of scale or different efficiencies by acting collectively.

In the quest for common goals to expand local supply capacity or limit, and further enhance access to business sectors; a coordinated or orchestrated treatment of trans-limit issues, for example, exchange and trade, administrative systems and strategies, territorial framework and different cross-border issues; and the administration of shared characteristic assets. Finally, the argument driven by this paper or caries forms the basis of the choice of the countries that were assumed to have more power to champion the integration efforts for the continent which are South Africa and Nigeria, the most industrialised and biggest economy respectively. These two countries can pursue their influence through institutions of higher learning in the continents (scholars), through the parliament of Africa although it does not have much power but that platform can be used for advocacy to other member states. However, among African Union member states, there is evidence of reluctance on the part of African leaders because they talk about the benefits of economic integration in Africa but they do not act. They know the importance of integration but are not acting aggressively for its achievement, evidence of political will that lacks. It is recommended that in order to pressure governments, the civil societies in Africa needs to be engaged to that they continue to engage their national governments as well as SADC, ECOWAS and AU leadership on the urgency and need positive strides towards achieving free trade corridors amongst African economies for the benefits of citizens through job creation and poverty alleviation.

\section{References}

Adeyemi, S. (2003). West African Leaders Agree on Deployment to Liberia. Jane's Defence Weekly 6 August 2003.

African Trade Report. (2018). Boosting Intra-African Trade: Implications of the African Continental Free Trade Area Agreement.

Candice, M. (2004). Regional integration and regional governance under the new African initiatives: a critical appraisal, Policy: issues \& actors, 17(3).

Cheru, F. (2002). African Renaissance: Roadmaps to the Challenge of Globalisation. Cape Town, New Africa Books/ David Phillip.

David, B., Diana, C., Thomas, K., Josaphat, K. \& Nichodemus, R. (2007). East African integration: How can it contribute to East African development?

Dey, I. (2005). Qualitative Data Analysis. London: Routledge, Taylor and Francis Group.

Enaifoghe, A. O. \& Adetiba, T. C. (2018). South African Economic Development and the SADC Sub-regional Integration, Journal of Economics and Behavioural Studies (JEBS), 10(1), 135-145.

Enaifoghe, A. 0. (2019). South Africa's Politics of Regional Integration in SADC and its Socio-Economic Implications. Journal of African Foreign Affairs (JoAFA), 6(1).

Langenhove, L. (2004). Towards a Regional World Order, UN Chronicle, 41(3), 12-13. 
Makame, A. (2012). The East African integration: Achievement and challenges, GREAT Insights, 1(6).

Martin, M. (2005). The State of Africa: A History of Fifty Years of Independence, London, Free Press, 44.

Mauro Boianovsky. (2000). In search of a canonical history of macroeconomics in the interwar period: Haberler's Prosperity and Depression revisited

Mogalakwe, M. (2006). Research Report. The Use of Documentary Research Methods in Social Research. African Sociological Review, 10(1), 221-230.

Mouton, J. (2001). Understanding Social Research. Pretoria: Van Schaik Publishers.

Njinkeu, D. \& Mangeni, F. (2004). Streamlining the process of economic integration in Africa, International Lawyers and Economists against Poverty (iLEAP), 4, 1-16.

Robson, P. (1968). Economic Integration in Africa, London: George Allen and Unwin Ltd, p. 11.

SADC. (2003). The Southern African Development Community - SADC History, Evolution and Current Status. http://www.sadc.int/index.php?lang=english\&path=about/background\&page=history

Schenoni, Luis. (2017). Subsystemic Unipolarities, Power Distribution and State Behaviour in South America and Southern Africa, in Strategic Analysis, 41(1), 74-86.

The World Bank. (2013). Regional Integration in Africa: Overview.

UN Economic Commission for Africa. (1999). Economic Report on Africa 1999: The Challenge of Poverty Reduction and Sustainability.

United Nations Economic Commission for Africa. (2006). Assessing Regional Integration in Africa: Rationalising Regional Economic Communities [Online].

United Nations Economic Committee for Africa. (2017). UMA - Arab Maghreb Union. Retrieved 03 April 2017.

Yahoo News. \& AFP. (2017). The 5 previous West African military interventions. Yahoo News AFP 20 January 2017. 